\title{
TESTE COLORIMÉTRICO EM GRÃOS DE PÓLEN DE Passiflora caerulea, $P$. foetida, $P$. miniata e $P$. mucronata
}

\author{
Kalia Dável Grecco' \\ Katiuss Ferreira Borges ${ }^{2}$ \\ Milene Miranda Praça-Fontes ${ }^{3}$
}

\begin{abstract}
Resumo: A análise de viabilidade polínica de espécies de Passiflora L. é importante para cruzamentos em melhoramento genético, pois obtêm-se a taxa de fertilidade masculina. Nesse sentido, o presente trabalho teve como objetivo caracterizar a taxa de viabilidade polínica de quatro espécies de Passiflora: P. caerulea, P. foetida, P. miniata e P. mucronata. Para as análises de viabilidade foi utilizado técnica de coloração citoquímica, utilizando os corantes: Lugol, Orceína e solução de Alexander. Os botões florais foram coletados e fixados em solução de metanol: acido acético (3:1) e mantidos sob refrigeração. Foram preparadas lâminas e analisadas ao microscópio óptico, considerando grãos de pólen viáveis e não viáveis, através da diferenciação colorimétrica e de tamanho. A contagem foi de 1000 grãos de pólen por lâmina. $P$. mucronata foi a espécie que apresentou os melhores resultados de viabilidade de pólen, diferindo estatisticamente de P. foetida, P. miniata e P. caerulea, quando os corantes Lugol e Orceína foram utilizados. Quando a solução de Alexander foi utilizada P. mucronata diferiu de P. foetida e P. miniata. Os menores valores de viabilidade dos pólens foram observados para P. foetida.
\end{abstract}

Palavras-chave: Maracujás; Passiflora L.; Orceína acética; Lugol; Viabilidade do pólen.

\footnotetext{
1 Graduanda em Ciências Biológicas/Universidade Federal do Espírito Santo, Brasil. E-mail: kaliagrecco@hotmail.com.

2 Mestre em Produção Vegetal/Universidade Federal do Espírito Santo, Brasil. E-mail: katiborgesbio@gmail.com.

3 Professora do Departamento de Biologia/Universidade Federal do Espírito Santo, Brasil. E-mail: milenemiranda@yahoo.com.br.
} 